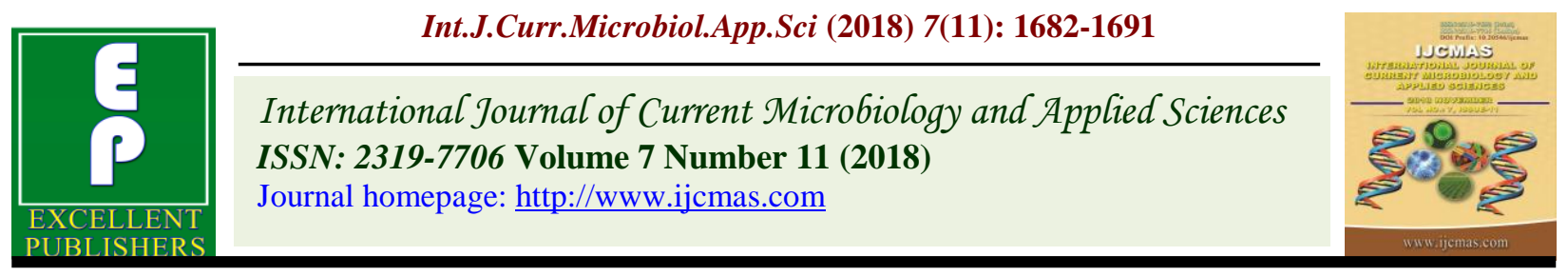

Original Research Article

https://doi.org/10.20546/ijcmas.2018.711.192

\title{
Abundance of Major Insect-Pests Infesting Green Gram and its Associated Natural Enemies
}

\author{
M.K. Jat, B.S. Rana, G. Chhangani*, M.K. Mahla and A. Vyas \\ Department of Entomology, Rajasthan College of Agriculture, Maharana Pratap University of \\ Agriculture and Technology, Udaipur, Rajasthan-313001, India \\ *Corresponding author
}

\section{A B S T R A C T}

\begin{tabular}{|l|}
\hline Ke y w o r d s \\
Green gram, Insect pests, \\
Natural enemies, \\
Seasonal incidence
\end{tabular}

The present investigation on abundance of major insect-pests infesting green gram and its associated natural enemies was carried at Instructional farm and Department of Entomology, Rajasthan College of Agriculture, MPUAT, Udaipur. Green gram variety SML-668 was sown on $18^{\text {th }}$ July during kharif 2015 and $16^{\text {th }}$ July during kharif 2016 with the seed rate of $15 \mathrm{~kg} / \mathrm{ha}$; maintaining a row to row and plant to plant spacing of $30 \mathrm{~cm} \mathrm{x}$ $10 \mathrm{~cm}$, respectively. Major insect pests, viz., aphids, Aphis craccivora (Koch); jassids, Empoassca spp., white flies, Bemisia tabaci (Gennadius); blister beetle, Mylabris spp. and spotted pod borer, Maruca vitrata (Geyer) were recorded under the prevailing agroclimatic conditions of the region. Greengram was also infested by other minor insect pests, viz., hairy caterpillar, tobacco caterpillar, plant bug and pod sucking bug. The associated natural enemies, viz., coccinellids, Coccinella septempunctata (L); Cheilomenes sexmaculata (Fab.) and syrphid flies were recorded feeding aphids on greengram; besides, spiders and wasps were also collected from the crop area.

\section{Introduction}

Pulses, the food legumes, have been grown by farmers since millennia providing nutritionally balanced food to the people of India (Nene, 2006) and many other countries of the world. Pulses are the major source of protein in the vegetarian diet in our country. Besides being a rich source of protein, they maintain soil fertility through biological nitrogen fixation in soil and thus play a vital role in furthering sustainable agriculture (Kannaiyan, 1999).

India is the largest producer of pulses in the world and has 25.26 million hectares area under cultivation with 16.47 million tons production and a productivity of $652 \mathrm{~kg} /$ hectare (Anonymous, 2015-16). The area covered under pulses in our country is 15.35 per cent of the total cropped area. Rajasthan, M.P. Haryana, Orissa, Maharashtra and U.P. account for 83.77 per cent of the total national area under pulses. In India, about 5.71 million hectares area is under organic cultivation and total production of organic produce is 1.35 million tons (APEDA, 2015-16). The total area and production in India under green gram were 3.83 million hectare and 1.60 million tons, respectively, with the productivity of 418 kg/ hectares (Anonymous, 2015-16); whereas, 
in Rajasthan total area and production under green gram was 13.73 lakh hectares and 5.97 lakh tons with the productivity of $438 \mathrm{~kg} / \mathrm{ha}$ (Anonymous, 2015-16). An estimated 200 insect pests that belong to 48 families in orders viz., Coleoptera, Diptera, Hemiptera, Hymenoptera, Isoptera, Lepidoptera, Orthoptera, Thysanoptera and 7 mites of order Acarina are known to infest greengram and blackgram. The major insect pests of green gram are aphids, Aphis craccivora Koch; jassids, Empoasca kerri Pruthi; white flies, Bemisia tabaci Gennadius, thrips belonging to genus Megalurothrips sp. and Caliothrips indicus Bagnall; the plant bugs viz., Riptortus pedestris Fabricius, Nezara viridula L., Plautia fimbriata Fabricius and the pod bug, Clavigralla gibbosa Spinola, spotted pod borer, Maruca vitrata Geyer and field bean pod borer, Adisura atkinsoni Moore (Talekar, 1990). They cause significant damage to greengram foliage and pods, besides causing damage to other related legumes.

\section{Materials and Methods}

In order to study the quantitative abundance of major insect-pests and their associated natural enemies of greengram, a field trial was laid out in uniformly sized plots measuring $5 \mathrm{~m} \mathrm{x} 5$ $\mathrm{m}$ (25 sq. $\mathrm{m}$.) and replicated thrice. Greengram variety SML-668 was sown on $18^{\text {th }}$ July during kharif 2015 and $16^{\text {th }}$ July during kharif 2016 with the seed rate of $15 \mathrm{~kg} / \mathrm{ha}$; maintaining a row to row and plant to plant spacing of $30 \mathrm{~cm} \times 10 \mathrm{~cm}$, respectively.

All other recommended agronomic practices were followed as per package of practices to raise a good crop. Weekly meteorological data on mean atmospheric temperature, mean relative humidity and total rainfall were obtained from the Meteorology Unit at the Instructional farm of Rajasthan College of Agriculture, Maharana Pratap University of Agriculture and Technology, Udaipur.

\section{Observation}

The population of different insect-pests and their associated natural enemies were recorded weekly from five randomly selected and tagged plants in each plot during morning hours between $6: 30$ a.m. to 8.00 a.m. for most of the insect species and from 9:00 a.m. to 11:00 a.m. for blister beetles.

\section{Sampling techniques}

The sampling techniques adopted for estimating the populations of different insect pests were as follows:

\section{Insect pests}

\section{Jassids, aphids and whiteflies}

Visual counting method was used to record the population of sucking pests viz., jassids, aphids and whiteflies from 5 randomly selected and tagged plants in each replicate. The total number of adults and nymphs of jassids and whiteflies were counted on the entire tagged plants; whereas, the aphids were counted from $5 \mathrm{~cm}$ floral twigs during early hours of the day $(6: 30-8: 00$ a.m.). An aspirator was used to collect necessary sample insects for further identification. A hand-held magnifying lens $(6 \mathrm{X})$ with LED illumination was used to count the insects in the field.

\section{Blister beetle}

Population of blister beetle was recorded by visual count for 2 hours during 9-11 a.m. from 5 plants randomly selected in each replication.

\section{Spotted pod borer}

The incidence was recorded in terms of mean pod damage by counting the total number of pods and the number of damaged pods at each picking, later the mean damage was calculated 
after pooling all the pickings by using the following formula:

No. of infested pods x 100 Mean infestation $(\%)=$

$$
\text { No. of total pods }
$$

\section{Natural enemies}

The associated natural enemies including larvae of syrphid flies, adult \& grubs of coccinellids and spiders were recorded weekly by visual count from the same five plants per replication on which the pest insects were observed.

\section{Statistical analysis}

In order to study the influence of key abiotic factors on the pest incidence and natural enemy complex, simple correlations were worked out between the incidence of insect pests/natural enemies and abiotic factors.

Population data of different insect pests and the natural enemy thus obtained were subjected to statistical analysis to find out the co-efficient of correlation with abiotic factors using following formula (Fowler et al., 1998).

$$
r_{x y}=\frac{\sum X Y-\frac{\left(\sum X\right)\left(\sum Y\right)}{n}}{\sqrt{\left[\sum X^{2}-\frac{\left(\sum X\right)^{2}}{n}\right]\left[\sum Y^{2}-\frac{\left(\sum Y\right)^{2}}{n}\right]}}
$$

Where,

$\mathrm{r}_{\mathrm{xy}}=$ Simple correlation coefficient

$\mathrm{X}=$ Variable i.e. abiotic component. (Average temperature and relative humidity)

$\mathrm{Y}=$ Variable i.e. mean number of insect pests

$\mathrm{n}=$ Number of paired observations
The correlation coefficient ( $r$ ) values were subjected to the test of significance using ttest:

$$
t=\frac{\mathrm{r}}{\sqrt{1-r^{2}}} \times \sqrt{\mathrm{n}-2}{\underset{\sim \mathrm{t}_{\mathrm{n}-2 \text { d.f. }}}{ }}
$$

The calculated t-value obtained was compared with tabulated $\mathrm{t}$-value at $5 \%$ level of significance.

\section{Results and Discussion}

\section{Aphid [Aphis craccivora (Koch)]}

The observations recorded on seasonal incidence of aphids revealed that aphid infestation initiated in the $3^{\text {rd }}$ week of August ( $33^{\text {rd }}$ SMW) during both the 2015 and 2016. The population increased gradually and reached to its peak in the $1^{\text {st }}$ week of September $\left(36^{\text {th }} \mathrm{SMW}\right)$ with mean population of 43.31 aphids/5 plants in 2015 and 36.96 aphids/5 plants in 2016 (Table 1).

\section{Jassid [Empoassca spp.]}

Jassid infestation initiated in the $2^{\text {nd }}$ week of August (32 $2^{\text {st }}$ SMW) during 2015 and 2016. The population increased gradually and reached to its peak in the $4^{\text {th }}$ week of August ( $34^{\text {th }}$ SMW) with mean population of 25.67 jassids $/ 5$ plants in 2015 and 25.35 jassids $/ 5$ plants in 2016. Thereafter, the population declined and reached to a minimum level of 4.0 jassids $/ 5$ plants in 2015 and 4.42 jassids $/ 5$ plants in 2016. Jassids population exhibited a significant negative correlation $(r=-0.73)$ with mean temperature and a significant positive correlation $(\mathrm{r}=0.71)$ with mean relative humidity during 2016.

\section{Whitefly [Bemisia tabaci (Gennadius)]}

Whitefly infestation was first observed in the $2^{\text {nd }}$ week of August (32 $2^{\text {st }}$ SMW) during 2015. 
The population increased gradually and reached to its peak in the last week of August $\left(35^{\text {th }} \mathrm{SMW}\right)$ with mean population of 24.45 whiteflies/ 5 plants. At the peak, the mean atmospheric temperature and mean relative humidity were $27.2^{\circ} \mathrm{C}$ and 69.95 per cent, respectively. Whereas, whitefly infestation was first observed in the $2^{\text {nd }}$ week of August $\left(32^{\text {st }}\right.$ SMW) during 2016. The population increased gradually and reached to its peak in the last week of August ( $35^{\text {th }}$ SMW) with mean population of 22.26 whiteflies/5 plants. At the peak, the mean atmospheric temperature, mean relative humidity and total rainfall were $26.95{ }^{\circ} \mathrm{C}, 80.25$ per cent and 14.4 mm during 2016.

\section{Blister beetle (Mylabris spp.)}

The incidence of blister beetle in greengram initiated in the $4^{\text {th }}$ week of August $\left(34^{\text {th }}\right.$ SMW) during 2015. The population increased gradually and reached to its peak in the $1^{\text {st }}$ week of September (36 ${ }^{\text {th }}$ SMW) with mean population of 11.36 beetles/5 plants. At the peak, the mean atmospheric temperature and mean relative humidity were $26.3{ }^{\circ} \mathrm{C}$ and 62.45 per cent respectively.

The incidence of blister beetle in greengram initiated in the $4^{\text {th }}$ week of August (34 $4^{\text {th }}$ SMW) during 2016 (Table 3). The population increased gradually and reached to its peak in the $1^{\text {st }}$ week of September $\left(36^{\text {th }}\right.$ SMW) with mean population of 10.62 adults $/ 5$ plants. At the peak, the mean atmospheric temperature and mean relative humidity were $26.05{ }^{\circ} \mathrm{C}$, 68.20 per cent during 2016.

\section{Spotted pod borer [Maruca vitrata (Geyer)]}

Spotted pod borer larvae infestation started in the $4^{\text {th }}$ week of August ( $34^{\text {th }}$ SMW) with a mean population of 1.8 larvae/5 plants during 2015. The population increased gradually and reached to its peak in the $2^{\text {nd }}$ week of September $\left(37^{\text {th }}\right.$ SMW) with mean population of 8.77 larvae/5 plants. The mean atmospheric temperature and relative humidity at the peak period were $28.65{ }^{\circ} \mathrm{C}$ and 56.00 per cent respectively. Spotted pod borer larvae infestation started in the $4^{\text {th }}$ week of August $\left(34^{\text {th }} \mathrm{SMW}\right)$ with a mean population of 2.2 larvae/5 plants during 2016. The population increased gradually and reached to its peak in the $2^{\text {nd }}$ week of September ( $37^{\text {th }}$ SMW) with mean population of 7.82 larvae/5 plants. The mean atmospheric temperature and relative humidity at the peak period were $26.75^{\circ} \mathrm{C}$ and 63.7 per cent during 2016.

\section{Natural enemies}

\section{Syrphid flies}

Syrphid fly population was first observed in the $4^{\text {th }}$ week of August ( $34^{\text {th }}$ SMW) during 2015. The population increased gradually and reached to its peak in the $1^{\text {st }}$ week of September $\left(36^{\text {th }} \mathrm{SMW}\right)$ with mean population of $3.15 / 5$ plants. At the peak, the mean atmospheric temperature and mean relative humidity during 2015 were $26.3{ }^{\circ} \mathrm{C}$ and 62.45 per cent respectively. Similarly, syrphid fly larvae population was first observed in the $4^{\text {th }}$ week of August (34 ${ }^{\text {th }}$ SMW) during 2016. The population increased gradually and reached to its peak in the $2^{\text {nd }}$ week of September $\left(37^{\text {th }}\right.$ SMW) with mean population of $2.74 / 5$ plants. At the peak, the mean atmospheric temperature and mean relative humidity during 2016 were $26.75^{\circ} \mathrm{C}$ and 63.7 per cent (Table 2).

Coccinellids [Coccinella septempunctata (L.) and Cheilomenes sexmaculata (Fab.)] grubs and adults

The coccinellid occurrence initiated in the $4^{\text {th }}$ week of August ( $34^{\text {th }}$ SMW) during 2015. The population increased gradually and reached to its peak in the $1^{\text {st }}$ week of September $\left(36^{\text {th }}\right.$ SMW) with mean population of $10.45 / 5$ plants. 
Table.1 Influence of abiotic factors on the incidence of major insect pests infesting greengram during kharif, 2015

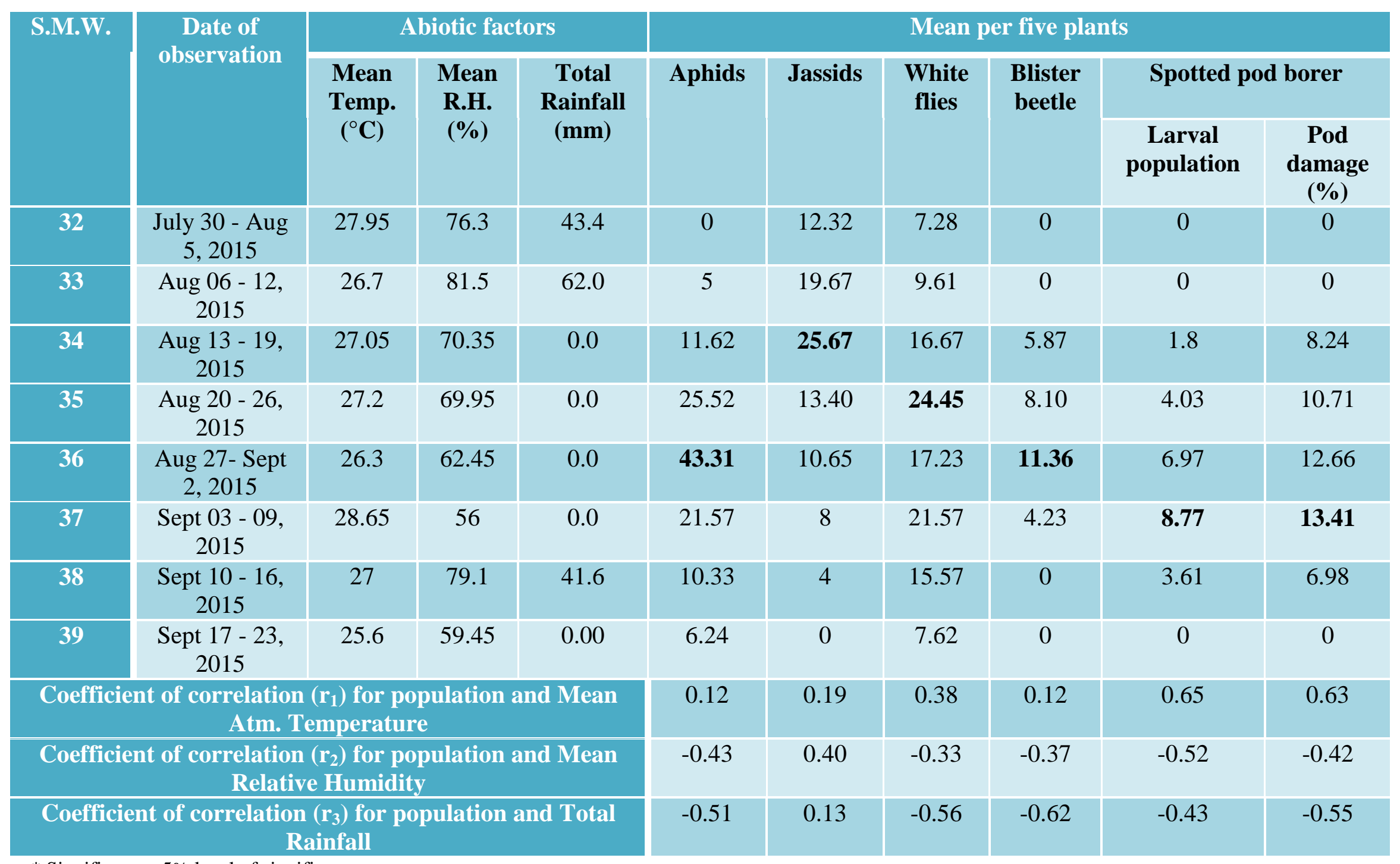

* Significant at $5 \%$ level of significance 
Table.2 Influence of abiotic factors on the incidence of natural enemies of greengram during kharif, 2015

\begin{tabular}{|c|c|c|c|c|c|c|c|}
\hline \multirow[t]{2}{*}{ S.M.W. } & \multirow[t]{2}{*}{ Date of observation } & \multicolumn{3}{|c|}{ Abiotic factors } & \multicolumn{3}{|c|}{ Mean per five plants } \\
\hline & & $\begin{array}{c}\text { Mean } \\
\text { Temp. } \\
\left({ }^{\circ} \mathrm{C}\right)\end{array}$ & $\begin{array}{c}\text { Mean } \\
\text { R.H. } \\
(\%)\end{array}$ & $\begin{array}{c}\text { Total } \\
\text { Rainfall } \\
(\mathbf{m m})\end{array}$ & $\begin{array}{l}\text { Syrphid fly } \\
\text { (maggots) }\end{array}$ & $\begin{array}{l}\text { Coccinellids } \\
\text { (grubs \& adults) }\end{array}$ & Spiders \\
\hline 32 & July 30 - Aug 5, 2015 & 27.95 & 76.3 & 43.4 & 0.00 & 0.00 & 0.00 \\
\hline 33 & Aug 06 - 12, 2015 & 26.7 & 81.5 & 62.0 & 0.00 & 0.00 & 0.00 \\
\hline 34 & Aug $13-19,2015$ & 27.05 & 70.35 & 0.0 & 1.42 & 3.21 & 1.05 \\
\hline 35 & Aug 20 - 26, 2015 & 27.2 & 69.95 & 0.0 & 2.12 & 6.42 & 1.52 \\
\hline 36 & Aug 27- Sept 2, 2015 & 26.3 & 62.45 & 0.0 & 3.15 & 10.45 & 2.25 \\
\hline 37 & Sept $03-09,2015$ & 28.65 & 56 & 0.0 & 2.42 & 6.90 & 2.98 \\
\hline 38 & Sept $10-16,2015$ & 27 & 79.1 & 41.6 & 1.00 & 2.72 & 1.42 \\
\hline 39 & Sept $17-23,2015$ & 25.6 & 59.45 & 0.00 & 0.75 & 1.23 & 1.15 \\
\hline \multicolumn{5}{|c|}{ Coefficient of correlation $\left(r_{1}\right)$ for population and Mean Atm. Temperature } & 0.33 & 0.29 & 0.53 \\
\hline \multicolumn{5}{|c|}{ Coefficient of correlation $\left(r_{2}\right)$ for population and Mean Relative Humidity } & -0.62 & -0.53 & -0.75 \\
\hline \multicolumn{5}{|c|}{ Coefficient of correlation $\left(\mathbf{r}_{3}\right)$ for population and Total Rainfall } & -0.71 & -0.60 & -0.64 \\
\hline
\end{tabular}

* Significant at $5 \%$ level of significance 
Table.3 Influence of abiotic factors on the incidence of major insect pests infesting greengram during kharif, 2016

\begin{tabular}{|c|c|c|c|c|c|c|c|c|c|c|}
\hline \multirow[t]{3}{*}{ S.M.W. } & \multirow{3}{*}{$\begin{array}{c}\text { Date of } \\
\text { observation }\end{array}$} & \multicolumn{3}{|c|}{ Abiotic factors } & \multicolumn{6}{|c|}{ Mean per five plants } \\
\hline & & \multirow{2}{*}{$\begin{array}{c}\text { Mean } \\
\text { Temp. } \\
\left({ }^{\circ} \mathrm{C}\right)\end{array}$} & \multirow{2}{*}{$\begin{array}{c}\text { Mean } \\
\text { R.H. } \\
(\%)\end{array}$} & \multirow{2}{*}{$\begin{array}{c}\text { Total } \\
\text { Rainfall } \\
(\mathbf{m m})\end{array}$} & \multirow[t]{2}{*}{ Aphids } & \multirow[t]{2}{*}{ Jassids } & \multirow{2}{*}{$\begin{array}{l}\text { White } \\
\text { flies }\end{array}$} & \multirow{2}{*}{$\begin{array}{l}\text { Blister } \\
\text { beetle }\end{array}$} & \multicolumn{2}{|c|}{ Spotted pod borer } \\
\hline & & & & & & & & & $\begin{array}{c}\text { Larval } \\
\text { population }\end{array}$ & $\begin{array}{c}\text { Pod } \\
\text { damage } \\
(\%)\end{array}$ \\
\hline 32 & $\begin{array}{l}\text { July } 30 \text { - Aug } 5 \text {, } \\
2016\end{array}$ & 25.15 & 92 & 104.5 & 0 & 11.43 & 6.97 & 0 & 0 & 0 \\
\hline 33 & Aug 06 - 12, 2016 & 26.5 & 74.6 & 0.6 & 5 & 17 & 9.83 & 0 & 0 & 0 \\
\hline 34 & Aug $13-19,2016$ & 25.4 & 85 & 61.2 & 13 & 25.35 & 11.97 & 7 & 2.2 & 9.00 \\
\hline 35 & Aug 20 - 26, 2016 & 26.95 & 80.25 & 14.4 & 29 & 18.67 & 22.26 & 8.93 & 3.17 & 10.71 \\
\hline 36 & $\begin{array}{l}\text { Aug 27- Sept 2, } \\
2016\end{array}$ & 26.05 & 68.2 & 0.0 & 36.96 & 12 & 18.13 & 10.62 & 5.97 & 12.03 \\
\hline 37 & Sept $03-09,2016$ & 26.75 & 63.7 & 0.0 & 25.36 & 9.23 & 13.73 & 7.23 & 7.82 & 13.29 \\
\hline 38 & Sept $10-16,2016$ & 28.95 & 64.6 & 3.4 & 18.97 & 4.42 & 6.23 & 3.15 & 3.37 & 6.98 \\
\hline 39 & Sept 17 - 23, 2016 & 28.7 & 58.35 & 0.00 & 9.21 & 0 & 2.12 & 0 & 0 & 0 \\
\hline \multicolumn{5}{|c|}{$\begin{array}{l}\text { Coefficient of correlation }\left(r_{1}\right) \text { for population and Mean } \\
\text { Atm. Temperature }\end{array}$} & 0.11 & $-0.73^{*}$ & -0.41 & -0.56 & -0.25 & -0.42 \\
\hline \multicolumn{5}{|c|}{$\begin{array}{l}\text { Coefficient of correlation }\left(r_{2}\right) \text { for population and Mean } \\
\text { Relative Humidity }\end{array}$} & -0.37 & $0.71 *$ & 0.24 & 0.37 & -0.17 & 0.21 \\
\hline \multicolumn{5}{|c|}{$\begin{array}{l}\text { Coefficient of correlation }\left(r_{3}\right) \text { for population and Total } \\
\text { Rainfall }\end{array}$} & -0.54 & 0.35 & -0.19 & 0.26 & -0.16 & 0.19 \\
\hline
\end{tabular}

* Significant at $5 \%$ level of significance 
Table.4 Influence of abiotic factors on the incidence of natural enemies of greengram during kharif, 2016

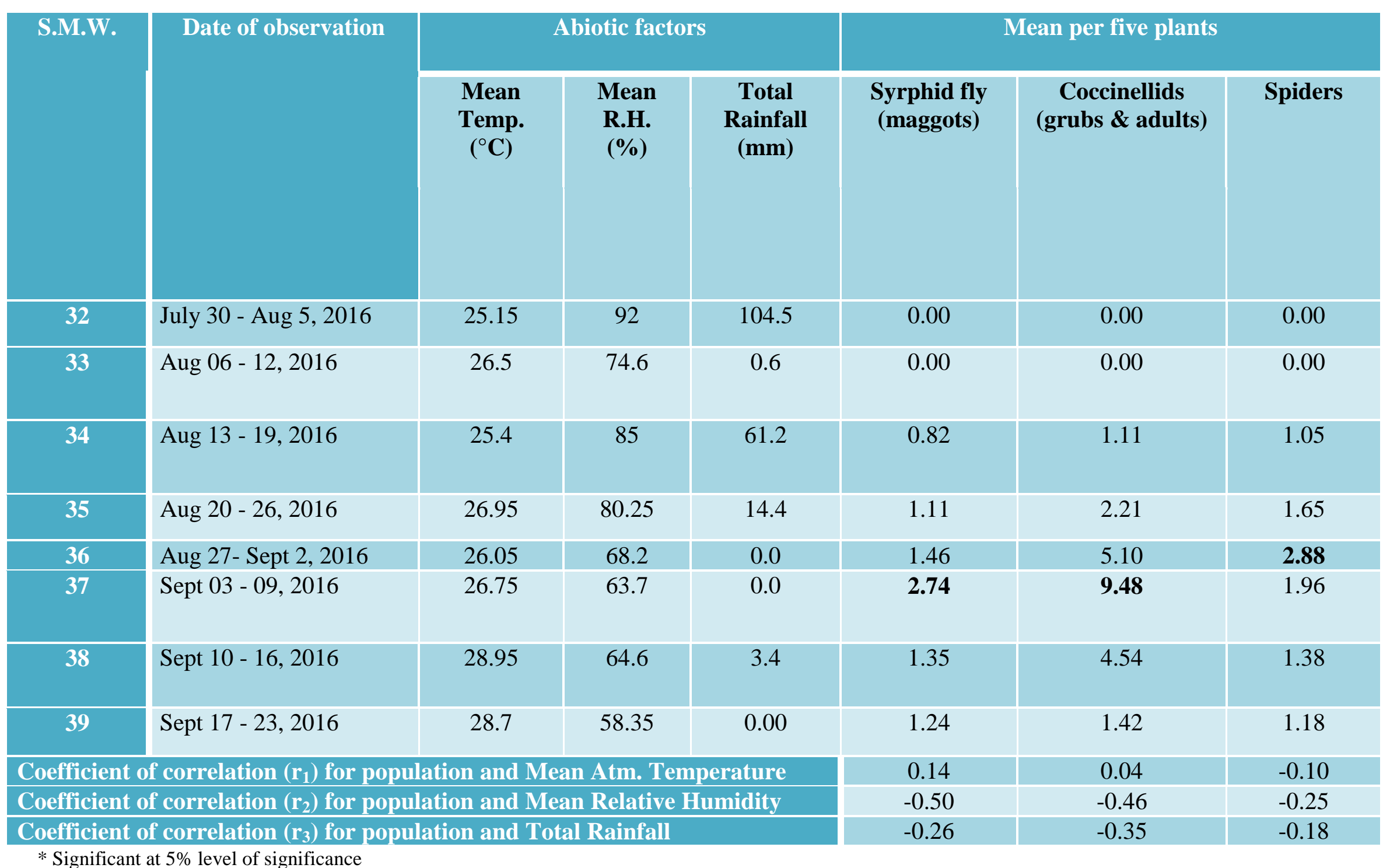


At the peak, the mean atmospheric temperature and mean relative humidity during 2015 were $26.3{ }^{\circ} \mathrm{C}$ and 62.45 per cent respectively. The coccinellid initiated in the $4^{\text {th }}$ week of August $\left(34^{\text {th }}\right.$ SMW) during 2016. The population increased gradually and reached to its peak in the $2^{\text {nd }}$ week of September $\left(37^{\text {th }}\right.$ SMW) with mean population of $9.48 / 5$ plants during 2016 . At the peak, the mean atmospheric temperature and mean relative humidity during 2016 were $26.75^{\circ} \mathrm{C}$ and 63.7 per cent respectively (Table 4).

\section{Spiders}

Spider population was first observed in the $4^{\text {th }}$ week of August ( $34^{\text {th }}$ SMW) during 2015. The population increased gradually and reached to its peak in the $2^{\text {nd }}$ week of September $\left(37^{\text {th }}\right.$ SMW) with mean population of $2.98 / 5$ plants. At the peak, the mean atmospheric temperature and mean relative humidity during 2015 were $28.65{ }^{\circ} \mathrm{C}$ and 56 per cent respectively. While, spider population was first observed in the $4^{\text {th }}$ week of August (34 ${ }^{\text {th }}$ SMW) during 2016. The population increased gradually and reached to its peak in the $1^{\text {st }}$ week of September $\left(36^{\text {th }}\right.$ SMW). At the peak, the mean atmospheric temperature and mean relative humidity during 2016 were $26.05^{\circ} \mathrm{C}$ and 68.2 per cent

From the available literature, pest incidence studies on greengram are scanty, however, the work on greengram during kharif has been reviewed are presented Umbarkar et al., (2010) observed that the population density of spotted pod borer on greengram was 0.75 larvae per plant during $5^{\text {th }}$ week after sowing $\left(32^{\text {nd }}\right.$ standard week) that reached to a peak of 3.81 larvae per plant in $34^{\text {th }}$ standard week $\left(7^{\text {th }}\right.$ week after sowing). Among the weather parameters, minimum temperature exhibited highly significant negative correlation with the spotted pod borer population $(\mathrm{r}=-0.559)$. Jain et al., (2013) reported that the aphid, A. craccivora, jassid, E. kerri and whitefly, B. tabaci infested the greengram in the last week of July 2013; while the incidence of blister beetle, $M$. pustulata and pod borer initiated in the fourth week of August and third week of August during 2013, respectively. The population of aphid, jassid, whitefly, blister beetle and pod borer attained its peak during second week of August (36.75/5 plants), first week of September $(27.67 / 5$ plants), third week of August (34.5/5 plants), first week of September (10.67/5 plants) and second week of September (11.33/5 plants), respectively. Similar findings have also been reported by Pawar et al., (2014), Duraimurugan and Tyagi (2014), Singh and Singh (2014), Kumar and Kumar (2015) and Yadav et al., (2015).

The findings of the present investigation are in close agreement with the findings of Earlier Thejaswi et al., (2008) recorded natural enemies from field bean that included Campoletis chlorideae Uchida, Bracon sp., Herpector costalis (Str.), Cryptopeltis tenuis, ladybird beetles, mirids, syrphids, spiders and carabid predators. Rekha et al., (2009) recorded nine species of predatory coccinellids, of which 3 common species viz., Coccinella transversalis Fabricius, Menochilus sexmaculatus Fabricius and Brumoides suturalis Mulsant were found in cereals, pulses and vegetable crops.

Agarwal et al., (2010) enlisted 16 parasitoids and predators belonging to Dictyoptera, Neuroptera, Hemiptera, Hymenoptera, Diptera and Coleoptera.

\section{Acknowledgement}

The authors sincerely thank the Head, Department of Entomology, Dean, Rajasthan College of Agriculture and Director Research, MPUAT, Udaipur for providing the necessary facilities to conduct the research.

\section{References}

Agrawal, N., Srivastava, M., Tripathy, A. and Singh, A. 2010. Survey and monitoring of pests, parasites and predators of pulses crop in central and eastern Uttar Pradash. Journal of Plant Protection Sciences, 2: 45-52. 
Anonymous. 2015-16 Rajasthan agriculture Statistics at a glance http://www. agriculture.rajasthan.gov.in/content/agric ulture/hi.html

Anonymous. 2015-16. Govt of India, ministry of statistics and programme implementation, http://mospi.nic.in/ statistical-year-book-india/2017/177

APEDA, 2015-16 www.Apeda.gov.in

Duraimurugan P. and Tyagi, K. 2014. Pest spectra, succession and its yield losses in mungbean and urdbean underchanging climatic scenario. Legume Research - An International Journal, 37: 212-222.

Fowler, J., Cohen, L. and Jarvis, P. 1998. Practical Statistics for the Field Biology, John Wiley and Sons, $2^{\text {nd }}$ Edition, West Susex, England, pp. 260.

Jain, A. K., Ameta, O. P., Rana, B. S. and Jain, H. K. 2013. Seasonal incidence of major insect pests of greengram. Indian Journal of Applied Entomology, 27: 119-122.

Kannaiyan, S. 1999. Bioresource Technology for Sustainable Agriculture, Associated Publishing Company. New Delhi, pp: 422.

Kumar, A. and Kumar, A. 2015. Effect of abiotic and biotic factors on incidence of pests and predator in cowpea [Vigna unguiculata (L.) walp.]. Legume Research; 38: 121-125.

Nene, Y. L. 2006. Indian pulses through the millennia. Asian Agri-history, 10: 179202.

Pawar, K. S., Dhavan, S. P. and Wadaskar, R. M. 2014. Temporal and intraday abundance variations of blister beetle
(Mylabris phalerata) on greengram. The Bioscan, 9: 65-69.

Rekha, B. S., Ramakumar, J., Kandibene, M., Raguraman, S. and Swamiappan, M. 2009. Diversity of coccinellids in cereals, pulses, vegetables and in weeded and partially weeded rice-cowpea ecosystem in Madurai District of Tamil Nadu. Madras Agricultural Journal, 96: 251264.

Singh, C. and Singh N. N. 2014. Occurrence of insect-pests infesting cowpea (Vigna unguiculata walpers) and their natural enemy complex in associations with weather variables. Legume Research - An International Journal, 37: 658-664.

Talekar, N. S. 1990. Insect pests of mungbean and their control. libnts.avrdc.org.tw/ fulltext_pdf/eam0121.pdf.

Thejaswi, I., Mohan, I. N. and Manjunatha, M. 2008. Studies on population dynamics of pest complex of field bean (Lablab purpureus L.) and natural enemies of pod borers. Karnataka Journal of Agriculture Sciences, 21: 399-402.

Umbarkar, P. S., Parsana, G. J. and Jethva, D. M. 2010. Seasonal incidence of spotted pod borer, (Maruca vitrata Geyer) on greengram. Agriculture Science Digest, 30: $150-151$.

Yadav, S. K., Meena, A. and Bisht, R. S. 2015. Seasonal incidence of insect-pests of blackgram, Vigna mungo (Linn.) and its correlation with abiotic factors. Agriculture Science Digest, 35:146-148.

\section{How to cite this article:}

Jat, M.K., B.S. Rana, G. Chhangani, M.K. Mahla and Vyas, A. 2018. Abundance of Major InsectPests Infesting Green Gram and Its Associated Natural Enemies. Int.J.Curr.Microbiol.App.Sci. 7(11): 1682-1691. doi: https://doi.org/10.20546/ijcmas.2018.711.192 